\title{
Selection of maturity indices for compost derived from grape pomace
}

\author{
M. Martínez ${ }^{1,2^{*}}$, R. Ortega ${ }^{1}$, M. Janssens ${ }^{2}$, J. Angulo ${ }^{3}$ and P. Fincheira ${ }^{4}$ \\ ${ }^{1}$ Grupo de Investigación en Suelo, Planta, Agua y Ambiente (GISPA). Universidad Técnica Federico Santa \\ María. Santiago, Chile.Postal code: 7660251. *Corresponding author: maria.martinez@usm.cl.2TROPEN- \\ Tropical Crops, Institute of Crop Science and Resource Conservation INRES Bonn Universität, Bonn Germany \\ Auf dem Hugel 6, 53121 Bonn, PC. 53111. ${ }^{3}$ Monsanto Chile. Santiago, Chile. ${ }^{4}$ Programa de Doctorado en \\ Ciencias de Recursos Naturales. Universidad de La Frontera. Temuco, Chile.
}

\begin{abstract}
Compost quality is usually determined through chemical composition and sanitary parameters; however it is necessary to determine more precise maturity indices. The objective of this work was to identify sensitive properties to measure compost maturity using a novel approach based on quality indices. Nine mature compost piles were sampled and analyzed for extractable and total elements, $\mathrm{NH}_{4}-\mathrm{N} / \mathrm{NO}_{3}-\mathrm{N}$, electrical conductivity, $\mathrm{C} / \mathrm{N}$ ratio, humic and fulvic fractions, hydrolytic enzyme activities, radish germination, respiration $\mathrm{CO}_{2}$ and microbiological parameters. The results indicated that humic acid: fulvic acid ratio, total bacteria count, and hydrolytic enzyme activities were sensitive parameters to define compost maturity and more specific tools to explain microbial activity and humification degree along the curing phase. The proposed model could be used to evaluate compost maturity with good reliability.
\end{abstract}

Keywords: Compost quality, maturity indices, mathematical modeling.

\section{Introduction}

Currently, 200 million tons of wine grapes (Vitis vinifera L.) are yearly produced at world level out of which $15 \%$ are used for wine-making industry, producing a $30 \%$ of solid waste. Grape pomace is generated by the production of grape juice, reaching 9 million of tons per year (Teixeira et al., 2014). In Chile and Peru it is produced by the pisco and wine industries. Grape pomace can be directly composted in order to be reintroduced into vineyards to maintain organic matter levels and to comply with the increasing consumer demands for natural products and sustainable practices (Dwyer et al., 2014). The composting is carried out in four stages or phases, viz: mesophilic, thermophilic, mesophilic (third phase), and curing phase. To count with proper maturity indicators, especially during the curing phase have a great importance to ensure product quality (Paradelo et al., 2010). Therefore, the objective of the present work was to identify sensitive parameters as maturity indicators along the curing phase of compost. 


\section{Materials and Methods}

The study was performed during two years in the Coquimbo Region of Chile. Nine treatments corresponding to compost elaborated with different proportions of grape pomace, from pisco distillery and goat manure were evaluated during the first year. The second year, the best three treatments (mixtures) were composted again for further analyses (Table 1). Compost samples were collected to a $60-\mathrm{cm}$ depth from the pile surface. Microbiological analyses and germination index were performed according to the procedures described by Martinez et al. (2010). The enzymatic activities were evaluated according to the methods described by Avellaneda-Torres et al. (2013); $\mathrm{C}-\mathrm{CO}_{2}$ by titration method (Novo et al., 2015), heavy metals, C/N ratio and fulvic acids according to Thompson et al. (2001). In order to select the properties to be included within a compost maturity index (MI), the following steps were performed: i) each measured property was standardized obtaining a Z score, ii) each standardized property for each pile, and for all treatments together, was regressed against time. The outcome for these regressions could be a positive slope, a negative one, or a zero slope, which will mean no change of that particular property with respect to the initial time. The slope corresponded to the weight of each property. Frequency response was estimated by dividing the number of significant $(p<0.05)$ responses among the treatments over the total number of piles. Corrected weights were estimated by multiplying the average response coefficient (slope) times its frequency response. Final weights were rescaled to add to one. iii) A linear combination of the sensitive variables was performed, using the corrected coefficients of each significant variable, to build a maturity index (Ortega and Santibañez, 2007).
Maturity Index

$(\mathrm{MI})=\beta 1 * \mathrm{P} 1+\beta \_2 * \mathrm{P} 2+\beta 3 * \mathrm{P} 3+\ldots \ldots .+\beta \mathrm{k} * \mathrm{Pk}$, Where: $\beta_{1}$ to $\beta_{\mathrm{k}}$ are corrected weights for properties $\mathrm{P}_{1}$ to $\mathrm{P}_{\mathrm{k}}$. The maturity limit was determined by using the MI of the last sampling data (mature piles) and calculating a lower bound by subtracting the value value $t_{0,15} \frac{s}{\sqrt{n}} \quad$ from the median value. Standardized data were replaced into the equation, all treatments above the maturity limit, were considered mature piles. Analyses were performed in the software SAS.

\section{Results and Discussion}

During the composting process, a thermophilic phase was described for 3-18 weeks with an average temperature of $55-60{ }^{\circ} \mathrm{C}$, decreasing after the 20 th week. During the first season, $\mathrm{C} / \mathrm{N}$ ratio did not vary but potential enzymatic activity, microbial concentration and ammonium nitrogen $\left(\mathrm{NH}_{4}-\mathrm{N}\right)$ showed a significant decrease along maturity phases $(p<0.05)$. Therefore, acid phosphatase, urease, $\mathrm{NH}_{4}-\mathrm{N}$, bacterial and cellulolytic population were effective maturity indicators for the first season, but the sign for $\mathrm{NH}_{4}-\mathrm{N}$ was positive, contrary to the expected behavior, where it should decreases as the nitrification process continues, while the ratio $\mathrm{NH}_{4}-\mathrm{N} / \mathrm{NO}_{3}-\mathrm{N}$ has to be $<3$, indicating that the maturity stage was not completed. These statistical significant properties were used to design a mathematical model that could explain the maturity process (equation 1 ) MI1 $=0.42 \mathrm{U}-0.17$ Cellul $+0.16 \mathrm{NH}_{4}-\mathrm{N}-0.1355 \mathrm{AcP}-0.1 \mathrm{Bac}$. In the second season, the selected treatments ( 3,5 and 6$)$ were compared with immature compost (treatment 10). Results showed that $\mathrm{Ha} / \mathrm{Fa}$ ratio, some enzymes and germination index were sensitive during the maturity process, showing that hydrolytic enzyme activities tended to be lower at the end of the composting by exhaustion of organic substrates and stabilization of microbial 
metabolic rates; some enzymatic activities resulted significant different and were used to propose a second model (equation 2) to explain the differences between mature and non-mature grape pomace composting process. $M I 2=-0.642 \mathrm{CO}_{2}-1.12 \mathrm{AcP}-1.18 \mathrm{AlkP}-0.678 \mathrm{BGlu}-$ $1.57 \mathrm{UDH}+0.283 \mathrm{NH}_{4}-\mathrm{N}-1.3 \mathrm{Bact}+1.067 \mathrm{Ger}-$ $0.423 \mathrm{Fa}+1.69 \mathrm{Ha} / \mathrm{Fa}-0.733 \mathrm{C} / \mathrm{N}$. After replacing the standardized values for treatments 3, 5, 6 and 10 into MI2, it was evident that MI increased with time (Table 1; Figure 1). Interestingly, radish germination index increased by degradation or consumption of phytotoxic compounds, while, the positive tendency of $\mathrm{Ha} / \mathrm{Fa}$ can be explained by the humification process (Paradelo et al., 2010; Kazemi et al., 2014).
For the second season, the application of MI indicated that treatments reached the maturity after 240 days of composting, with significant differences with respect to the non-mature treatment $(p<0.05)$ (Nikaeen et al., 2015). Moreover, final products were characterized by having $\mathrm{pH} 7.9$, organic matter $=49 \%, \mathrm{C} / \mathrm{N}=12.8$, electrical conductivity $=3.35$ $\mathrm{dS} / \mathrm{m}$, germination index $=92 \%$, fecal coliform $=327$ $\mathrm{NMP} / \mathrm{g}, \mathrm{NH}_{4}-\mathrm{N} / \mathrm{NO}_{3}-\mathrm{N}=2.85$.

The results indicate that under these conditions, properties such as $\mathrm{Ha} / \mathrm{Fa}$, radish germination, enzymatic activities and microbial count are good indicators to build more accurate maturity indices (MI).

Table 1. Composition of evaluated treatments, parameters of characterization and Maturity index. Note: Compost piles (18 m length $\times 2 \mathrm{~m}$ width x $1.5 \mathrm{~m}$ height) were composted during winter-spring season and kept in maturity until spring-summer season. (Ten subsamples were randomly collected and mixed to form a composite sample; three composited samples per treatment were collected).

\begin{tabular}{|c|c|c|c|c|c|c|c|c|c|c|c|c|c|c|c|c|c|c|c|c|c|}
\hline \multirow[b]{3}{*}{$\mathrm{T}$} & & & $\mathrm{atm}$ & nt con & sition & & \multicolumn{10}{|c|}{$\begin{array}{l}\text { Heavy metal and sanitary parameters } \\
\text { (First season) }\end{array}$} & \multicolumn{3}{|c|}{$\begin{array}{l}\text { Maturity index } \\
\text { (First season) }\end{array}$} & \multicolumn{2}{|c|}{$\begin{array}{l}\text { Maturity index } \\
\text { (Second season) }\end{array}$} \\
\hline & $\mathrm{H}$ & G & $G$ & $G^{*}$ & $Y$ & $\mathbf{P}+\mathbf{O}$ & $\mathrm{Cr}$ & $\mathrm{Cu}$ & $\mathrm{Ni}$ & $\mathrm{Pb}$ & Cd & $\mathrm{Zn}$ & Ger & FC & E. coli & Salmonella sp. & 180 & 220 & 240 & 180 & 240 \\
\hline & & \multicolumn{5}{|c|}{$(\%)$} & \multicolumn{6}{|c|}{$\mathrm{mg} \mathrm{kg}^{-1}$} & $\%$ & \multicolumn{2}{|c|}{ MPN $100 \mathrm{~g}^{-1}$ DM } & MNP $4 \mathrm{~g}^{-1} \mathrm{DM}$ & \multicolumn{3}{|c|}{ Days } & \multicolumn{2}{|c|}{ Days } \\
\hline 1 & 1 & 0 & 89 & 0 & 0 & 10 & 15 & 33 & 6 & 4 & $<0.01$ & 35 & 95 & 31 & 0.23 & $<0.02$ & -0.64 & -0.85 & 0.38 & - & - \\
\hline 2 & 9 & 7 & 82 & 0 & 0 & 2 & 7 & 31 & 6 & 3 & $<0.01$ & 40 & 98 & 245 & 0.26 & $<0.02$ & -0.57 & -0.49 & 0.65 & - & - \\
\hline 3 & 0 & 0 & 91 & 0 & 0 & 5 & 13 & 30 & 6 & 4 & $<0.01$ & 35 & 94 & 6 & 0.24 & $<0.02$ & -0.47 & -0.56 & 0.48 & -0.32 & 0.58 \\
\hline 4 & 0 & 50 & 50 & 0 & 0 & 0 & 6 & 31 & 8 & 5 & $<0.01$ & 55 & 95 & 0 & 0.20 & $<0.02$ & -0.43 & -0.01 & 0.12 & & \\
\hline 5 & 0 & 63 & 33 & 0 & 0 & 4 & 10 & 31 & 8 & 9 & $<0.01$ & 56 & 100 & 0 & 0.21 & $<0.02$ & -0.44 & -0.66 & 1.2 & -0.70 & 0.60 \\
\hline 6 & 22 & 25 & 53 & 0 & 0 & 0 & 12 & 34 & 6 & 5 & $<0.01$ & 44 & 90 & 641 & 0.21 & $<0.02$ & -0.64 & -0.29 & 1.6 & -0.44 & 0.74 \\
\hline 7 & 21 & 26 & 21 & 28 & 0 & 4 & 18 & 33 & 8 & 5 & $<0.01$ & 43 & 98 & 480 & 0.22 & $<0.02$ & -0.38 & -0.57 & 1.9 & - & - \\
\hline 8 & 42 & 20 & 33 & 0 & 0 & 5 & 9 & 36 & 9 & 32 & $<0.01$ & 49 & 92 & 570 & 0.23 & $<0.02$ & -0.69 & -0.43 & 0.6 & - & - \\
\hline 9 & 0 & 66 & 34 & 0 & 0 & 0 & 13 & 31 & 9 & 5 & $<0.01$ & 48 & 93 & 613 & 0.24 & $<0.02$ & -0.11 & -0.36 & 1.5 & - & - \\
\hline $10^{*}$ & 0 & 2 & 30 & 0 & 60 & 8 & - & - & - & - & - & - & - & - & - & - & - & - & - & -0.65 & 0.20 \\
\hline A & 0 & 2 & 30 & 0 & 60 & 8 & 120 & 100 & 20 & 100 & 2 & 200 & $>80$ & $<1000$ & $\mathrm{Nd}$ & $<3$ & - & - & - & - & - \\
\hline B & - & - & - & - & . & - & 600 & 1000 & 80 & 300 & 8 & 2000 & $>80$ & $<1000$ & $\mathrm{Nd}$ & $<3$ & - & - & - & - & - \\
\hline
\end{tabular}

T: treatment; H: horse manure; G: goat manure; G: grape pomace-fresh G*: grape pomace-aged; Y: yeast and fermentation residues; P: pruning residues; O: oat straw; Ger: Germination; FC: Fecal coliforms.* Second Season. Note: General evaluation was made for the first nine treatments; the $10^{\text {th }}$ was proposed as immature treatment to compare the best three treatments in a $2^{\text {th }}$ season of evaluation. A-B* NTCh 2880/04.Nd: Not determined. (Conditions: semiarid environment and Mediterranean climate with thermal amplitude of $20^{\circ} \mathrm{C}$ mean annual temperature: $16.6^{\circ} \mathrm{C}$, and total precipitation of $150 \mathrm{~mm} \mathrm{y}^{-1}, 85 \%$ in winter) 
a)

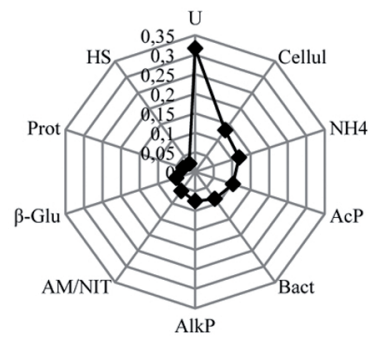

b)

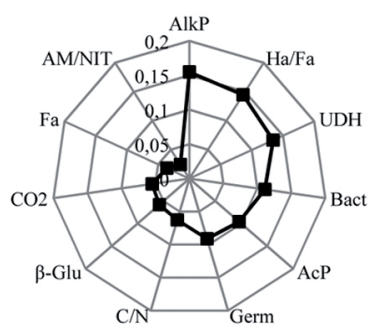

Figure 1. Parameters varying the most along maturity phase for a) first season and b) second season. U: Urease. Cellul: Cellulolytic microorganisms count. $\mathrm{NH}_{4}$ : ammonium-nitrogen. AcP: Acid phosphatase. Bact: Bacterial count. Prot: Proteolytic microorganisms count. HS: Humic and fulvic acids content. AlkP: Alkaline phosphatase. $\mathrm{Ha} / \mathrm{Fa}$ : Humic to fulvic acids ratio. UDH: Dehydrogenase. Germ: Radish germination index. C/N: Carbon to nitrogen ratio. $\beta$-Glu: $\beta$-Glucosidase. $\mathrm{CO}_{2}$ : Respirometry. Fa: Fulvic acids content. AM/NIT: $\mathrm{NH}_{4}-\mathrm{Nto} \mathrm{NO}_{3}-\mathrm{N}$ ratio.

\section{Conclusions}

The proposed method to build maturity indices (MI) based on sensitive properties can be used to evaluate compost maturity and select the most appropriate mixtures of raw materials.
Microbial and enzymatic activities in conjunction with parameters that reflect humification process are essential indicators to evaluate compost maturity. 


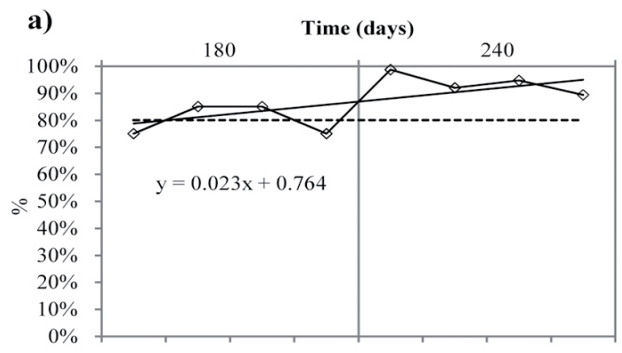

c)

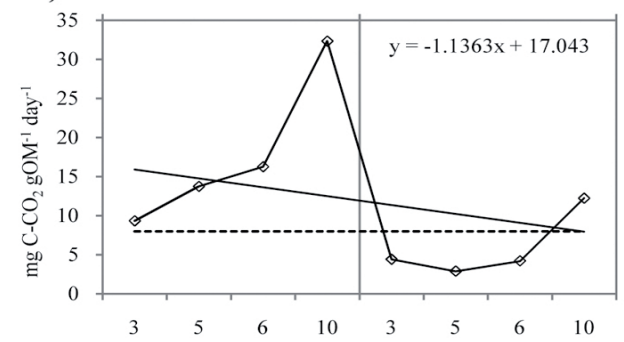

e)

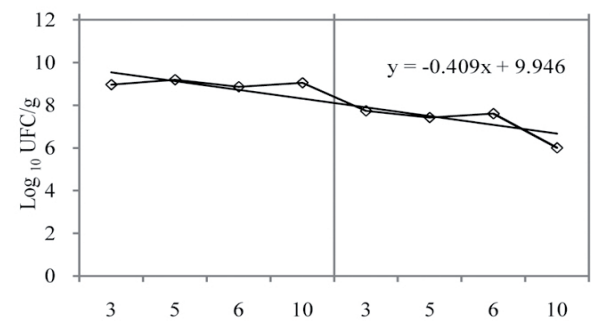

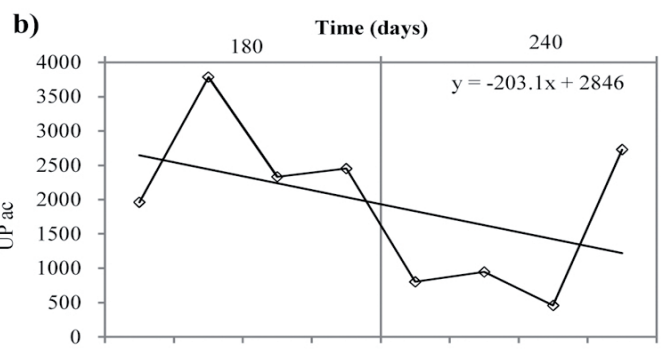

d)

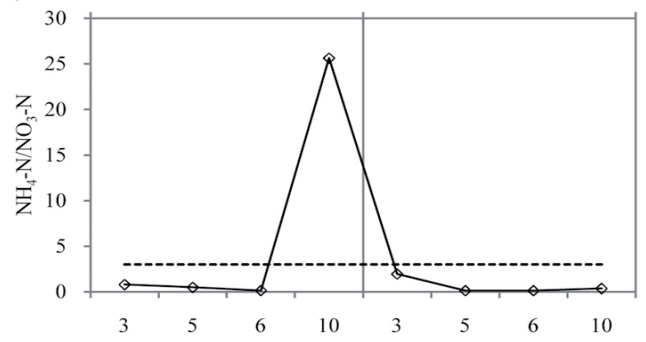

f)

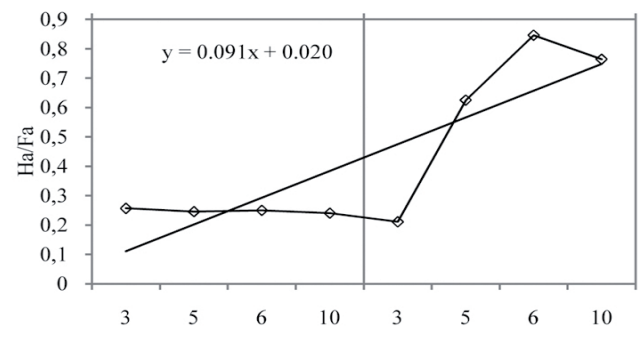

Treatments

Figure 2. Tendency of the different maturity parameters of each treatment for the second season: a) Radish germination index, b) Acid phosphatase activity (UPac), c) respirometry (mg C- $\mathrm{CO}_{2} \mathrm{~g} \mathrm{OM}_{-1}$ day $_{-1}$ ), d) ammonium-N to nitrate-N ratio $\left(\mathrm{NH}_{4}-\mathrm{N} / \mathrm{NO}_{3}-\mathrm{N}\right)$, e) Bacterial count $\left(\log _{10} \mathrm{UFC} / \mathrm{g}\right)$ and f) Humic to fulvic content ratio $(\mathrm{Ha} / \mathrm{Fa})$. Dotted lines indicates maturity limits stablished by NCh 2880-2004. 


\section{Acknowledgments}

Proyecto FONDECYT 1130975.

\section{References}

Avellaneda-Torres, L.M., Melgarejo, L.M., NarváezCuenca, C.E., Sánchez, J. 2013. Enzymatic activities of potato crop soils subjected to conventional management and grassland soils. J. Soil Sci. Plant Nutr. 13, 301-312.

Dwyer, K., Hosseinian, F., Rod, M. 2014. The Market Potential of Grape Waste Alternatives. J Food Res. 3, 91- 106.

Kazemi, K., Zhang, B., Lye, L., Lin, W. 2014. Performance of locally available bulking agents in Newfoundland and Labrador during bench-scale municipal solid waste composting. Environ. Syst. Res. 3, 22.

Martínez, M., Gutiérrez, V., Novo, R. 2010. Microbiología aplicada al manejo sustentable de suelos y cultivos. Editorial Universidad Técnica Federico Santa María. Santiago, Chile. 235p.

Novo, R., Martínez, M., Ortega, Ospina, P,, Carrascal, A. 2015. Manual de prácticas clásicas en microbiología y bioquímica para el estudio de suelos, bioproductos y materiales orgánicos. Editorial Universidad Técnica Federico Santa María. Santiago, Chile. 137 p.
Nikaeen, M., HosseinNafez, A., Bina, B., Fatemeh Nabavi, B., Hassanzadeh, A. 2015. Respiration and enzymatic activities as indicators of stabilization of sewage sludge composting. Waste Manage. $39,104-110$.

Ortega, R., Santibáñez, O. 2007. Agronomic evaluation of three zoning methods based on soil fertility in corn crops (Zea mays L.). Comput Electron. Agr. 58, 49-59.

Paradelo, R., Moldes, A.B., Prieto, B., Sandu, R.G., Barral, B.T. 2010. Can Stability and Maturity Be Evaluated in Finished Composts from Different Sources?. Compost SciUtil. 8, 22-31.

Teixeira, A., Baenas, N., Domínguez-Perles, R., Barros, A., Rosa, E., Moreno, D., García-Viguera, C. 2014. Natural Bioactive Compounds from Winery By-Products as Health Promoters: A Review. Int. J. Mol. 15, 15638-15678.

Thompson, W., Leege, P., Millner, P., Watson, M. 2001. Test Methods for Examination of Composting and Compost (TMECC). The US Composting Council Research and Education Foundation and the United States Department of Agriculture. United States. TMECC 